\title{
Novel Sequential Screening and Enhanced Production of Fibrinolytic Enzyme by Bacillus sp. IND12 Using Response Surface Methodology in Solid-State Fermentation
}

\author{
Ponnuswamy Vijayaraghavan, ${ }^{1}$ P. Rajendran, ${ }^{2}$ Samuel Gnana Prakash Vincent, ${ }^{1}$ \\ Arumugaperumal Arun, ${ }^{3}$ Naif Abdullah Al-Dhabi, \\ Mariadhas Valan Arasu, ${ }^{4}$ Oh Young Kwon, ${ }^{5}$ and Young Ock Kim ${ }^{6}$ \\ ${ }^{1}$ Centre for Marine Science and Technology, Manonmaniam Sundaranar University, Rajakkamangalam, Kanyakumari District, \\ Tamil Nadu 629 502, India \\ ${ }^{2}$ Kanyakumari Field Centre, Central Marine Fisheries Research Institute, Kanyakumari, Tamil Nadu 629702, India \\ ${ }^{3}$ Department of Biotechnology, Kalasalingam University, Srivilliputtur, Virudhunagar, Tamil Nadu 626126, India \\ ${ }^{4}$ Department of Botany and Microbiology, Addiriyah Chair for Environmental Studies, College of Science, King Saud University, \\ P. O. Box 2455, Riyadh 11451, Saudi Arabia \\ ${ }^{5}$ Department of Medical Education and Medical Humanities, School of Medicine, Kyung Hee University, Seoul, Republic of Korea \\ ${ }^{6}$ Department of Medicinal Crop Research, RDA, Eumseong, Chungbuk 369-873, Republic of Korea
}

Correspondence should be addressed to Ponnuswamy Vijayaraghavan; venzymes@gmail.com and Mariadhas Valan Arasu; mvalanarasu@gmail.com

Received 8 August 2016; Revised 30 November 2016; Accepted 13 December 2016; Published 22 February 2017

Academic Editor: Denise Freire

Copyright (C) 2017 Ponnuswamy Vijayaraghavan et al. This is an open access article distributed under the Creative Commons Attribution License, which permits unrestricted use, distribution, and reproduction in any medium, provided the original work is properly cited.

\begin{abstract}
Fibrinolytic enzymes have wide applications in clinical and waste treatment. Bacterial isolates were screened for fibrinolytic enzyme producing ability by skimmed milk agar plate using bromocresol green dye, fibrin plate method, zymography analysis, and goat blood clot lysis. After these sequential screenings, Bacillus sp. IND12 was selected for fibrinolytic enzyme production. Bacillus sp. IND12 effectively used cow dung for its growth and enzyme production ( $687 \pm 6.5 \mathrm{U} / \mathrm{g}$ substrate). Further, the optimum bioprocess parameters were found out for maximum fibrinolytic enzyme production using cow dung as a low cost substrate under solidstate fermentation. Two-level full-factorial experiments revealed that moisture, $\mathrm{pH}$, sucrose, peptone, and $\mathrm{MgSO}_{4}$ were the vital parameters with statistical significance $(p<0.001)$. Three factors (moisture, sucrose, and $\mathrm{MgSO}_{4}$ ) were further studied through experiments of central composite rotational design and response surface methodology. Enzyme production of optimized medium showed $4143 \pm 12.31 \mathrm{U} / \mathrm{g}$ material, which was more than fourfold the initial enzyme production $(978 \pm 36.4 \mathrm{U} / \mathrm{g})$. The analysis of variance showed that the developed response surface model was highly significant $(p<0.001)$. The fibrinolytic enzyme digested goat blood clot $(100 \%)$, chicken skin $(83 \pm 3.6 \%)$, egg white $(100 \%)$, and bovine serum albumin $(29 \pm 4.9 \%)$.
\end{abstract}

\section{Introduction}

Fibrinolytic enzymes are used as thrombolytic agents to treat cardiovascular diseases and stroke. The plasminogen activator molecules, namely, urokinase, streptokinase, and tissue plasminogen activator, are commonly used in thrombolytic therapy but are expensive and also have unintended physiological effects like bleeding complication, low fibrin specificity, and short half-lives [1]. Hence, the search for the effective and safe thrombolytic agent from different biosources keeps growing worldwide. Study reports are available on fibrinolytic enzymes from various organisms, including Bacillus polymyxa [2], Escherichia coli [3], Pseudomonas [4], Streptomyces [5], Paenibacillus sp. IND8 [6], and Bacillus cereus IND1 [7]. Fibrinolytic enzymes have the ability to inhibit blood coagulation and are able to degrade the fibrin [8]. These enzymes have been reported to be produced in 
both solid-state fermentation (SSF) and submerged fermentation processes.

SSF has emerged as a useful method for production of enzymes and many significant pharmaceutical products. In a SSF process, usage of convenient substrate is one of the important factors and the yield is considerably higher than submerged fermentation [9]. Agroindustrial residues like wheat bran [9], pigeon pea [10], potato peel [11], grass powder [12], and chicken feather [13] were used for the production of enzymes. Apart from these agroindustrial wastes, researchers attempted to use various effluents including dairy and tannery industrial effluents for the production of proteolytic enzymes. These industrial wastes are rich in nitrogen and carbon sources. Several studies have proved the potential use of these industrial wastes to minimize pollution and to increase the product yield $[14,15]$. The marine food waste, shrimp peptone, was also shown to be a potential substrate for SSF involving the production of proteases, recently [16]. The agricultural wastes such as peanut shell, corncob, pomace of corn, and peels of cassava were used for the production of tetracycline [17]. The antibiotic, Cephamycin C, was produced in SSF using wheat straw, deoiled cake of cotton seed, sunflower cake, and corn steep liquor [18] and wheat bran and sweet lemon peel was used as the substrate for the production of nigerloxin in SSF [19]. Apple pomace and chickpeas were used as the substrate for fibrinolytic enzyme production in SSF by Bacillus cereus GD55 [20] and Bacillus amyloliquefaciens [21].

Generally, enzyme production in a bioprocess is significantly influenced by medium components such as nitrogen and carbon sources and physical factors such as inoculum, $\mathrm{pH}$, temperature, and incubation time [22]. The cost of medium components is one of the critical factors in an industrial perspective, because approximately one-third of the production cost of enzyme was attributed to growth medium cost [23]. Hence, the utilization of locally available inexpensive substrates could bring down the production cost [24]. Medium optimization is also an important factor in enzyme bioprocess. Optimized media enhance the enzyme yield and reduce the production cost. Optimization of process parameters through a one-factor-at-a-time approach is useful; however, it fails to provide the interactions between the variables or factors. The effective method is statistical optimization wherein the medium components having the most significant effect on bioprocess can be identified and optimized [25].

Central composite rotational design (CCRD) and response surface methodology (RSM) elucidate the best-yielding concentration of each factor in the fermentation process. The number of variables that can be studied with lower number of experiments is more in RSM. This saves cost and time and makes RSM more effective than classical methods [26]. RSM has been applied to various cases of enzyme production [27-29]. In recent years, proteolytic enzymes have attracted much more attention for their hydrolytic activity toward recalcitrant animal proteins such as keratin [30] and amyloid prion proteins [31] and collagen [32] and blood clot [33] and management of industrial and medical wastes. Screening of the significant factors was elucidated by two-level full-factorial design and optimization of the significant variables using RSM [25]. Bacterial fibrinolytic enzymes, especially Bacillus sp., can be effectively utilized to cure or prevent cardiovascular diseases [34]. In the present study, sequential optimization strategy was followed to enhance fibrinolytic enzyme production from Bacillus sp. IND12 utilizing cow dung as the solid substrate.

\section{Materials and Methods}

\subsection{Screening}

Step 1 (screening of protease-producing organisms). Soil, fish, and rice were used as the sample sources for the production of fibrinolytic enzyme. Soil sample was collected from an agricultural field. Rice was boiled for $45 \mathrm{~min}$ and allowed for aerobic fermentation for a period of $48 \mathrm{~h}$ at room temperature $\left(30 \pm 2^{\circ} \mathrm{C}\right)$ and used as the source of bacteria. The marine fish, Sardinella longiceps, was collected from Kanyakumari Coast, Tamil Nadu, India, for the isolation of marine bacterial isolates. One gram of sample was transferred to an Erlenmeyer flask $(100 \mathrm{~mL})$ with $50 \mathrm{~mL}$ of double-distilled water. It was shaken for $10 \mathrm{~min}$ and this was resuspended in distilled water and aliquots were spread on skimmed milk agar plates (skimmed milk, 10; beef extract, 1.5; peptic digest of animal tissue, 5.0; yeast extract, 1.5; sodium chloride, 5.0; agar, 1.5; bromocresol green, $0.015[\mathrm{~g} / \mathrm{L}], \mathrm{pH}, 7.0)$ [35]. For marine isolates, $3 \%(\mathrm{v} / \mathrm{w})$ sodium chloride was added with the culture medium. The potent proteolytic enzyme-producing bacterial isolate was calculated on the basis of $P_{z}$ value as described by Price et al. [36]. The bacterial isolate with low $P_{z}$ value was considered for optimization of enzyme production.

$P_{z}$ value was calculated by using the following equation:

$$
P_{z}=\frac{\text { Colon diameter }}{\text { Colon diameter }+ \text { Zone of precipitation }} .
$$

The isolated protease-producing bacteria were cultured individually in nutrient broth medium.

This was performed by inoculating $1 \%(\mathrm{v} / \mathrm{v})$ precultured protease positive isolates and incubated at $37^{\circ} \mathrm{C}$ for $48 \mathrm{~h}$. The cell-free supernatant was used as the source of fibrinolytic enzyme.

Step 2 (screening of fibrinolytic enzyme-producing bacterial isolates (secondary screening)). Fibrinolytic activity of the crude enzyme was tested in a fibrin plate composed of $0.1 \mathrm{M}$ sodium phosphate buffer ( $\mathrm{pH} 7.4), 1 \%(\mathrm{w} / \mathrm{v})$ agarose, $1.2 \%$ (v/v) fibrinogen, and thrombin (100 NIH units/mL). The fibrin plate was allowed to stand for $1 \mathrm{~h}$ at room temperature to form a fibrin clot layer. About $20 \mu \mathrm{L}$ of crude enzyme was dropped into holes and incubated at $37^{\circ} \mathrm{C}$ for $5 \mathrm{~h}$. The fibrinolytic enzyme exhibited a clear zone of degradation of fibrin around the well, thus indicating its fibrinolytic activity [37]. Ten organisms were screened, and potent organism was retained for this study. The potent isolate was subjected to biochemical characterization and $16 \mathrm{~S}$ rDNA sequencing.

Step 3 (fibrin zymography). Fibrin zymography was performed to determine fibrinolytic activity of protein having 
different molecular weight. Bovine fibrinogen $(0.12 \%)$ and bovine thrombin $(10 \mathrm{NIH} \mathrm{U/mL)}$ were copolymerized with $12 \%(\mathrm{w} / \mathrm{v})$ sodium dodecyl sulfate- (SDS-) polyacrylamide gel. After the electrophoresis run, the gel was incubated in $50 \mathrm{mM}$ Tris buffer ( $\mathrm{pH} 7.4$ ) containing 2.5\% (v/v) Triton X100 and incubated in zymogram reaction buffer (Tris buffer, $\mathrm{pH} 7.4$, and $50 \mathrm{mM}$ ) for $5 \mathrm{~h}$ at $37^{\circ} \mathrm{C}$. At the last step, the gel was subjected to staining with Coomassie Brilliant Blue R250 for a period of $1 \mathrm{~h}$, after which it was destained and bands corresponding to fibrinolytic activities were observed as the unstained regions [38].

Step 4 (in vitro blood clot lytic activity of fibrinolytic enzymes). The clot lytic activity was studied by incubating the crude extract with goat blood in vitro. The goat blood clot was severed into small pieces $(400 \pm 50 \mathrm{mg})$, and $200 \mathrm{U}$ streptokinase (positive control), sodium phosphate buffer (negative control), and $200 \mathrm{U}$ fibrinolytic enzyme were added. Then the mix was incubated at $30 \pm 2^{\circ} \mathrm{C}$ for $24 \mathrm{~h}$, and the results were observed. Based on primary and secondary screening, fibrin zymography, and in vitro blood clot lytic activity of the crude fibrinolytic enzyme, the potent organism was selected for further studies.

2.2. Identification of Potent Strain. The screened bacterial strain IND12 with highest fibrinolytic enzyme activity was identified based on biochemical characters [39] and 16S rRNA gene sequencing [40]. The genomic DNA of the strain IND12 was extracted by using a QIAGEN kit (Germany). The $16 \mathrm{~S}$ rRNA gene of the strain was amplified using the upstream primer (P1: $5^{\prime}$-AGAGTTTGATCMTGGCTAG-3') and the downstream primer (P2: $5^{\prime}$-ACGGGCGG TGTGTRC-3') (Sigma-Aldrich). The amplified product was sequenced and sequence comparison with databases was performed using BLAST through the NCBI server [41]. The isolated bacterium was identified as Bacillus sp. IND12. The $16 \mathrm{~S}$ rDNA sequence was submitted in GenBank database under the accession number KF638633.

2.3. Maintenance of Culture. Bacillus sp. IND12 was grown on nutrient agar slant which consisted of $0.5 \%(\mathrm{w} / \mathrm{v})$ peptic digest of animal tissue, $0.15 \%(\mathrm{w} / \mathrm{v})$ beef extract, $0.15 \%$ yeast extract, $0.5 \%$ sodium chloride, and $1.5 \%(\mathrm{w} / \mathrm{v})$ agar. The nutrient agar slant was incubated at $37^{\circ} \mathrm{C}$ for $24 \mathrm{~h}$ and the strain was stored at $-20^{\circ} \mathrm{C}$ as the glycerol stock.

2.4. Inoculum Preparation. Seed culture for fibrinolytic enzyme production was prepared by inoculating a loopful culture of this strain into nutrient broth medium (peptic digest of animal tissue, 5.0; beef extract, 1.5; yeast extract, 1.5; and sodium chloride, 5.0; [g/L]). The 250-mL culture flask was further incubated at $37^{\circ} \mathrm{C}$ for $24 \mathrm{~h}$ in a rotary shaker at $175 \mathrm{rpm}$ and used as inoculum.

2.5. Screening of Different Agroindustrial Waste Materials for the Production of Fibrinolytic Enzyme by Solid-State Fermentation. The substrates such as wheat bran and rice bran were collected from the local market. Green gram husk, tapioca peel, and banana peel were processed separately, and cow dung was collected from the farm house. All substrates were dried for seven days, powdered, and sieved (1.0-1.5 mm in size). $5.0 \mathrm{~g}$ of substrates was taken in Erlenmeyer flask individually and Tris buffer $(\mathrm{pH} 8.0,0.1 \mathrm{M})$ was added to maintain the moisture level $(100 \%, \mathrm{v} / \mathrm{w})$. The contents of the Erlenmeyer flasks were mixed and autoclaved at $15 \mathrm{lbs}$ for $15 \mathrm{~min}$. The Erlenmeyer flasks were inoculated with $10 \%$ inoculum $(0.810 \pm 0.250 \mathrm{OD}$ at $600 \mathrm{~nm})$ and incubated at $37^{\circ} \mathrm{C}$ for $72 \mathrm{~h} .50 \mathrm{~mL}$ double-distilled water was added to the fermented medium. It was placed in an orbital shaker for $30 \mathrm{~min}$ at $150 \mathrm{rpm}$ at room temperature $\left(30 \pm 2^{\circ} \mathrm{C}\right)$. The mixed slurry was squeezed through a cheese cloth and centrifuged at $4^{\circ} \mathrm{C}$ for $20 \mathrm{~min}$ at $10,000 \mathrm{rpm}$. The cell-free clear supernatant was used as the source of enzyme.

2.6. Fibrinolytic Enzyme Assay. Fibrinolytic enzyme was assayed by the hydrolysis of fibrin [42]. The reaction mixture contained $2.5 \mathrm{~mL}$ of fibrin $(1.2 \%$, w/v), $2.5 \mathrm{~mL}$ of Tris- $\mathrm{HCl}$ $(0.1 \mathrm{M})$ containing $0.01 \mathrm{M} \mathrm{CaCl}$ ( $\mathrm{pH} 7.8)$, and a suitable amount of enzyme. The incubation was carried out for $30 \mathrm{~min}$ $\left(37^{\circ} \mathrm{C}\right)$, and the measurement time fell within the linear portion of the progress curve. The reaction was stopped by adding $5 \mathrm{~mL}$ trichloroacetic acid (TCA) containing $0.22 \mathrm{M}$ sodium acetate and $0.33 \mathrm{M}$ acetic acid. The absorbance of the supernatant was measured at $275 \mathrm{~nm}$. One fibrinolytic enzyme unit was defined as the amount of sample that gave an increase in absorbency at $275 \mathrm{~nm}$ equivalent to $1 \mu \mathrm{g}$ of tyrosine per min at $37^{\circ} \mathrm{C}$.

2.7. Protease Assay. Casein was used as the substrate for determining the protease activity. The reaction mixture contained casein (prepared in $0.05 \mathrm{M}$ of Tris- $\mathrm{HCl}$ buffer, $\mathrm{pH} 8.0$ ) and $0.1 \mathrm{~mL}$ of enzyme solution. This mixture was incubated for $30 \mathrm{~min}$ at $37^{\circ} \mathrm{C}$ and the measurement time fell within the linear portion of the progress curve. The reaction was stopped by adding $2.5 \mathrm{~mL}$ of TCA $(0.11 \mathrm{M})$, and the mixture was centrifuged at $10,000 \times \mathrm{g}(10 \mathrm{~min})$. The optical density of the solution was read against sample blank at $280 \mathrm{~nm}$. One unit of the protease activity was defined as $1 \mu \mathrm{g}$ of tyrosine liberated per minute under assay conditions. The total protein content of the crude enzyme was determined as described by Lowry et al. [43].

2.8. Screening of Variables for the Production of Fibrinolytic Enzyme by One-Variable-at-a-Time Approach. The "onevariable-at-a-time" strategy was applied in order to optimize the various nutrient parameters required for fibrinolytic enzyme production. Cow dung $(5 \mathrm{~g})$ was used as the substrate for fibrinolytic enzyme production in SSF. Each subsequent nutrient factor was examined after taking into account the previously optimized factor. In the present study, the medium components such as carbon sources (1\% [w/w], sucrose, maltose, xylose, glucose, trehalose, and starch), nitrogen sources $(1 \%[\mathrm{w} / \mathrm{w}]$, casein, yeast extract, urea, gelatin, peptone, and beef extract), and inorganic salts $(0.1 \%$ w/w], calcium chloride, ammonium chloride, ferrous sulfate, ammonium sulfate, disodium hydrogen phosphate, sodium nitrate, magnesium chloride, and sodium dihydrogen phosphate) were tested. The enzyme was extracted as described earlier, 
and enzyme assay was carried out. All experiments were performed in triplicate and expressed as mean \pm standard deviation. Analysis of variance (ANOVA) was carried out to find the significance of variance.

\subsection{Selection of Significant Variables by $2^{5}$ Full-Factorial} Design. Two-level full-factorial design was employed to elucidate the relative importance of various medium components affecting fibrinolytic enzyme production. To determine the significant nutrient and physical factors for fibrinolytic enzyme production, five variables were selected. The variables used were moisture, $\mathrm{pH}$, sucrose, peptone, and $\mathrm{MgSO}_{4}$ at two levels (i.e., -1 and +1 ). The software Design-Expert (version 9.0.6) was used to design and analyze the data. The mean value of " -1 and +1 " was used to evaluate the average response of this model design.

$$
\begin{aligned}
Y= & \alpha_{0}+\sum_{i}^{\alpha_{i} x_{i}}+\sum \underset{i j}{\alpha_{i j} x_{i} x_{j}}+\sum_{i j k}^{\alpha_{i j k} x_{i} x_{j} x_{k}} \\
& +\sum \alpha_{i j k l} x_{i} x_{j} x_{k} x_{l}+\sum \sum_{i j k l} \alpha_{i j k l m} x_{j} x_{k} x_{l} x_{m}
\end{aligned}
$$

where $Y$ is the response, $\alpha_{i j}=i j \mathrm{th}, \alpha_{i j k}=i j k \mathrm{th}, \alpha_{i j k l}=$ $i j k l$ th, and $\alpha_{i j k l m}=i j k l m$ th interaction coefficients, $\alpha_{0}$ was an intercept, and $\alpha_{i}$ was the $i$ th linear coefficient.

2.10. Optimization of Medium Components by RSM. CCRD was employed to determine the best combination for fibrinolytic enzyme production. A total number of 20 sets of experimental runs with different combination of physical and nutrient factors were performed (14 noncentral points and 6 central points). Each variable was tested at five levels $(-\alpha,-1,0,+1$, and $+\alpha)$. The other factors such as peptone, $\mathrm{pH}$, and inoculum were set at middle level. The fibrinolytic enzyme activity was assayed in triplicate, and the average value was reported as response $(Y)$. The results obtained from this model were subjected to analysis of variance (ANOVA) for analyzing the regression coefficient. The results were best fitted with the second-order polynomial equation by a multiple regression technique. The combination of variables that showed the maximum response was determined, and the fitted model was validated. The suitability of the polynomial model equation was judged by determining $R^{2}$, and its significance was determined by $F$-test.

The second-order polynomial describing a system with three factors is as follows:

$$
Y=\beta_{0}+\sum \beta_{i=1}^{3} \beta_{i}+\sum \beta_{\substack{i i \\ i=1}}^{3} X_{i}^{2}+\sum \underset{\substack{i j=1 \\ \beta_{i j} X_{i j}}}{3}
$$

where $Y$ is the response (fibrinolytic activity), $\beta_{0}$ and $\beta_{i}$ are the offset and coefficients of linear terms, respectively, and $\beta_{i i}$ and $\beta_{i j}$ are the coefficients of square terms and coefficients of interactive terms, respectively. $X_{i}$ s were $A, B$, and $C ; X_{i j} \mathrm{~s}$ were $A B, A C$, and $B C$ ( $A$-coded value of moisture, $B$-coded value of sucrose, and $C$-coded value of $\mathrm{MgSO}_{4}$ ).

Design-Expert 9.0.6 was the statistical software used to design and analyze the experimental data. The fitted quadratic model of the experimental trial was expressed in the form of $3 \mathrm{D}$ response surface graphs. These $3 \mathrm{D}$ graphs illustrate the main effect and interactive effects of the independent factors on the dependent factor. The predicted conditions were used to perform experiments in order to validate the generated model.

2.11. Digestion of Proteins. Crude enzyme was appropriately diluted at $50 \mathrm{U} / \mathrm{mL}$ concentrations in $50 \mathrm{mM}$ Tris- $\mathrm{HCl}$ buffer ( $\mathrm{pH} 8.0$ ). In the present study, crude enzyme was incubated with goat blood clot $(1.0 \mathrm{~g})$, egg white $(1.0 \mathrm{~g})$, chicken skin $(1.0 \mathrm{~g})$, and bovine serum albumin $(1 \%, \mathrm{w} / \mathrm{v})$ for $24 \mathrm{~h}$ at room temperature $\left(30 \pm 2^{\circ} \mathrm{C}\right)$. The substrate that was incubated with buffer was considered as control. The remaining total protein was estimated and the digested protein content was calculated (\%).

\section{Results and Discussion}

Fibrinolytic treatment such as administration of urokinase intravenously is widely used but the enzyme is expensive, and there is risk of internal hemorrhage within the intestinal tract. So, research has been pursued to improve the thrombolytic therapy in terms of efficacy and specificity. In the present study many potent bacterial isolates were isolated from the soil sample, fishes, and cooked rice for the production of fibrinolytic enzymes.

3.1. Screening of Bacterial Isolate for Fibrinolytic Enzyme Production. The fibrinolytic enzyme produced by the bacterial isolate was primarily determined by skimmed milk agar plates. $P_{z}$ value was found to be much less for Bacillus sp. IND12 (0.20) and this low $P_{z}$ value indicated good protease production (Figure 1(a)). Fibrinolytic enzyme is a subclass of proteases and has an ability to degrade fibrin substrate [44]. Hence, in this study, the protease secreting ability of the bacterial isolates was initially screened using skimmed milk agar plates. All the selected 10 isolates showed fibrinolytic activity on this plate (Figure 1(b)). Fibrin plate method is the most suitable method for the determination of fibrinolytic activity from bacteria, fungi, and other sources. In addition to these, fibrin zymography and in vitro blood clot lytic activity of the crude enzyme of all ten isolates were studied. Most of the selected bacterial isolates synthesized more than one fibrinolytic enzyme. The molecular weight of the fibrinolytic enzyme ranges from 15 to $90 \mathrm{kDa}$ (Figure $1(\mathrm{c})$ ). The Bacillus sp. such as B. subtilis 168, B. subtilis CH3-5, B. amyloliquefaciens $\mathrm{CH} 51, B$. amyloliquefaciens $\mathrm{CH} 86$, and $B$. licheniformis $\mathrm{CH} 3-17$ produced more than one fibrinolytic enzyme at this range [45]. The fibrinolytic enzymes gradually dissolved blood clot within $24 \mathrm{~h}$ of incubation at room temperature $\left(30 \pm 2^{\circ} \mathrm{C}\right)$. Most of the bacterial fibrinolytic enzymes dissolved blood clot completely (Table 1). These results suggested that fibrinolytic enzymes had obvious effect on dissolving blood clot. This kind of clot lysis was reported with $B$. subtilis LD-8547 fibrinolytic enzymes [46]. Based on these four steps' screening procedure, IND12 showed potent activity. The selected organism was rod shaped and oxidaseand catalase-positive. It hydrolyzed casein and starch and 


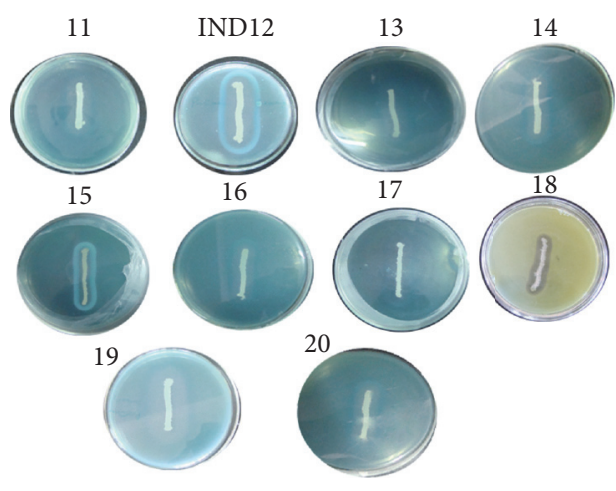

(a)

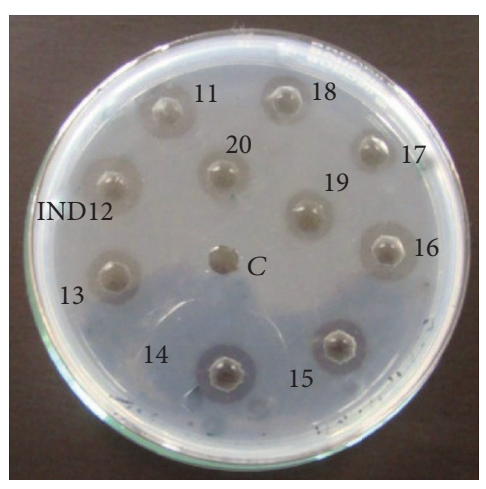

(b)

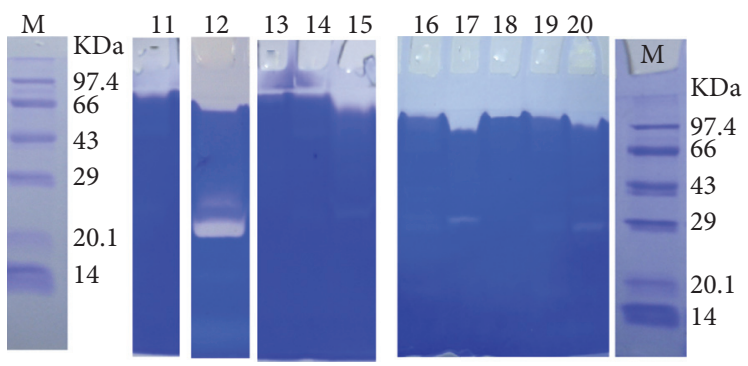

(c)

FIGURE 1: Screening of bacterial isolates for proteolytic activity. The strain IND12 showed a large halo zone compared to other tested bacterial isolates (a). Screening of fibrinolytic enzyme from the selected bacteria. Fibrinolytic activity appeared as a halo zone from the protease positive strains 11-20 (b). Fibrinolytic enzyme activity on SDS-PAGE. The strain IND12 showed potent activity (c).

TABLE 1: In vitro blood clot lytic activity of fibrinolytic enzymes from the bacterial isolates.

\begin{tabular}{lc}
\hline Bacterial strains & \% of blood clot lysis \\
\hline 11 & 100 \\
12 (IND12) & 100 \\
13 & $87 \pm 12$ \\
14 & $79 \pm 7.1$ \\
15 & 100 \\
16 & $98.3 \pm 14.8$ \\
17 & $63.7 \pm 10.9$ \\
18 & $53.4 \pm 1.2$ \\
19 & 100 \\
20 & 100 \\
\hline
\end{tabular}

tested negative for gelatin hydrolysis. It had tested negative for indole formation, citrate utilization, and $\mathrm{H}_{2} \mathrm{~S}$ production. The proteolytic enzyme production by any bacterial isolate mainly depends on the growth media and other physical factors. However, the optimum concentration of the medium varies from strain to strain [47]. Hence, it is important to screen the medium components and physical factors for the new bacterial isolates.

3.2. Cow Dung Is a Potential Medium for the Production of Fibrinolytic Enzyme. The bacterial isolate, Bacillus sp. IND12, utilized all tested agroindustrial residues for the production of fibrinolytic enzyme. This organism utilized cow dung
TABLE 2: Effect of agroresidues on fibrinolytic enzyme production in SSF.

\begin{tabular}{lc}
\hline Agroresidues & Fibrinolytic activity $(\mathrm{U} / \mathrm{g})$ \\
\hline Banana peel & 85 \\
Cow dung & 687 \\
Green gram husk & 493 \\
Rice bran & 273 \\
Tapioca peel & 384 \\
Wheat bran & 640 \\
\hline
\end{tabular}

effectively for its growth and fibrinolytic enzyme production. Enzyme production was high in the cow dung substrate $(687 \pm 6.5 \mathrm{U} / \mathrm{g})$ (Table 2$)$. The selection of an ideal substrate for enzyme production in SSF depends on several factors including availability and cost [9] and nutritive value of the medium [29]. Cow dung is one of the unexploited and most abundant feedstock for fibrinolytic enzyme production. It contains cellulose (35.4-37.6\%), hemicelluloses (32.6-34.1\%), ash (13.3-13.4\%), nitrogen (1.2-1.4\%), and other essential nutrients such as $\mathrm{Mg}, \mathrm{Ca}, \mathrm{Zn}, \mathrm{S}, \mathrm{Cu}, \mathrm{B}$, and $\mathrm{Mn}[48,49]$. The carbon, nitrogen, and other nutrients' content in cow dung are an indication that it could be a good nutrient source for the microbes [50]. The agroindustrial residues such as rice chaff [51], shrimp shells [4], cane molasses [52], and wheat bran [7] were used as the substrate for the production of fibrinolytic enzyme. The availability of cow dung substrate is higher than most of the reported substrates. Considering 
the availability and cost, cow dung is an ideal medium for the production of fibrinolytic enzyme from Bacillus sp. IND12. The growth of this strain on cow dung is important for the production of various industrially useful enzymes in cheap cost.

3.3. Effect of Carbon, Nitrogen, and Ionic Sources. To screen different carbon sources, $1 \%$ carbon source (maltose, glucose, sucrose, xylose, starch, and trehalose) was supplemented with cow dung substrate. This medium was inoculated with $10 \%$ inoculum $(0.810 \pm 0.250 \mathrm{OD}$ at $600 \mathrm{~nm})$ and incubated for $72 \mathrm{~h}$. All tested carbon sources enhanced fibrinolytic enzyme production (Figure 2). The influence of different carbon sources on fibrinolytic enzyme production was found to be statistically significant $(P<0.00001)$ by the oneway ANOVA. The lowest fibrinolytic enzyme activity was obtained with xylose $(648 \pm 11.5 \mathrm{U} / \mathrm{g})$ and highest enzyme activity was observed with sucrose $(1049 \pm 17.43 \mathrm{U} / \mathrm{g})$. Similar results were obtained in the study of Liu et al. [25] in the screening of the carbon sources on the fibrinolytic activity of Bacillus natto NLSSE. Considering the cheap cost and enzyme production, sucrose was chosen as the carbon source for further optimization study. To screen different nitrogen sources, $1 \%$ casein, peptone, beef extract, yeast extract, urea, and gelatin were supplemented with cow dung substrate. The lowest fibrinolytic activity was registered with urea (435 \pm $3.87 \mathrm{U} / \mathrm{g})$ and the highest with peptone $(1127 \pm 1.38 \mathrm{U} / \mathrm{g})$ (Figure 2). The influence of different nitrogen sources on fibrinolytic enzyme production was found to be statistically significant $(P<0.00001)$ by the one-way ANOVA. Similar results were obtained with Bacillus subtilis RJAS19 [53] and Streptomyces sp. [54]. From this result, peptone was chosen as the nitrogen source for further optimization study. The culture medium was supplemented with $0.1 \%$ ions such as calcium chloride, ammonium chloride, ferrous sulfate, ammonium sulfate, disodium hydrogen phosphate, sodium nitrate, and sodium dihydrogen phosphate. Enzyme production was found to be high in the medium containing $\mathrm{MgSO}_{4}$ as the ionic source. The ions such as $\mathrm{Ca}^{2+}$ and $\mathrm{Mn}^{2+}$ also enhanced the production of fibrinolytic enzyme, and enzyme activity was $867.4 \pm 4.9$ and $912.6 \pm 3.8 \mathrm{U} / \mathrm{g}$, respectively (Figure 2 ). The influence of different ionic sources on fibrinolytic enzyme production was found to be statistically significant $(P<$ $0.00001)$ by the one-way ANOVA. In this study, $\mathrm{Ca}^{2+}$ ions also positively regulated enzyme production. The positive effect of divalent ions such as $\mathrm{Mg}^{2+}$ and $\mathrm{Mn}^{2+}$ was reported by Pillai et al. [55] with Bacillus subtilis P13. The stimulating effect of $\mathrm{CaCl}_{2}$ was also stated by Mabrouk et al. [56]. The presence of other components at $0.1 \%$ level did not positively influence the enzyme production.

\subsection{Studies on the Effect of Process Variables on Fibrinolytic} Enzyme Production by $2^{5}$ Full-Factorial Design. The significance of five medium components, namely, moisture $(A)$, $\mathrm{pH}(B)$, sucrose $(C)$, peptone $(D)$, and $\mathrm{MgSO}_{4}(E)$, for the production of fibrinolytic enzyme was elucidated as given by $2^{5}$ full-factorial design. The factors and their levels were described in detail (Table 3 ). The $2^{5}$ full-factorial experiment
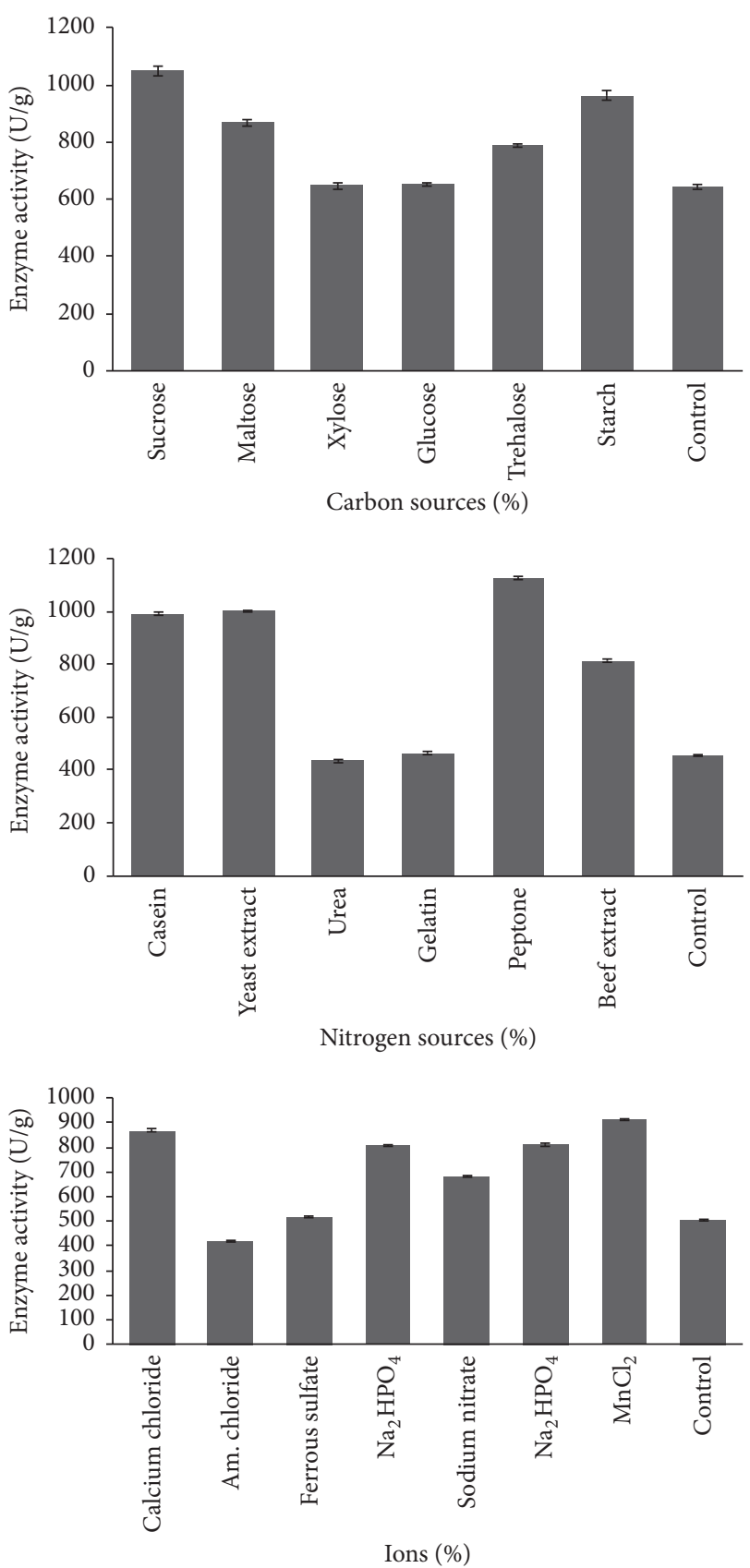

FIGURE 2: Effect of carbon sources, nitrogen sources, and ions on fibrinolytic enzyme production by Bacillus sp. IND12. These nutrient sources were supplemented individually with cow dung substrate, inoculated with $10 \%$ inoculum $(0.810 \pm 0.250 \mathrm{OD}$ at $600 \mathrm{~nm})$, and incubated at $37^{\circ} \mathrm{C}$ for $72 \mathrm{~h}$.

TABLE 3: Variables and their levels for $2^{5}$ full-factorial design.

\begin{tabular}{lcccc}
\hline \multirow{2}{*}{ Symbol } & Variable name & \multirow{2}{*}{ Units } & \multicolumn{2}{c}{ Coded levels } \\
& & & -1 & +1 \\
\hline$A$ & Moisture & $\%$ & 90 & 120 \\
$B$ & $\mathrm{pH}$ & & 7 & 9 \\
$C$ & Sucrose & $\%$ & 0.1 & 1 \\
$D$ & Peptone & $\%$ & 0.1 & 1 \\
$E$ & $\mathrm{MgSO}_{4}$ & $\%$ & 0.01 & 0.1 \\
\hline
\end{tabular}


TABLE 4: Two-level full-factorial design for selection of significant process variables for fibrinolytic enzyme production from Bacillus sp. IND12.

\begin{tabular}{|c|c|c|c|c|c|c|}
\hline Run & $\begin{array}{c}\text { Moisture } \\
(A)\end{array}$ & $\begin{array}{l}\mathrm{pH} \\
(B)\end{array}$ & $\begin{array}{l}\text { Sucrose } \\
(C)\end{array}$ & $\begin{array}{l}\text { Peptone } \\
(D)\end{array}$ & $\begin{array}{c}\mathrm{MgSO}_{4} \\
(E)\end{array}$ & Enzyme activity $(\mathrm{U} / \mathrm{g})$ \\
\hline 1 & 1 & 1 & 1 & 1 & 1 & 1920 \\
\hline 2 & -1 & 1 & 1 & 1 & 1 & 1419 \\
\hline 3 & 1 & -1 & 1 & 1 & 1 & 3949 \\
\hline 4 & -1 & -1 & 1 & 1 & 1 & 3122 \\
\hline 5 & 1 & 1 & -1 & 1 & 1 & 1473 \\
\hline 6 & -1 & 1 & -1 & 1 & 1 & 1949 \\
\hline 7 & 1 & -1 & -1 & 1 & 1 & 1166 \\
\hline 8 & -1 & -1 & -1 & 1 & 1 & 1521 \\
\hline 9 & 1 & 1 & 1 & -1 & 1 & 3184 \\
\hline 10 & -1 & 1 & 1 & -1 & 1 & 1466 \\
\hline 11 & 1 & -1 & 1 & -1 & 1 & 1032 \\
\hline 12 & -1 & -1 & 1 & -1 & 1 & 1066 \\
\hline 13 & 1 & 1 & -1 & -1 & 1 & 1702 \\
\hline 14 & -1 & 1 & -1 & -1 & 1 & 3881 \\
\hline 15 & 1 & -1 & -1 & -1 & 1 & 1590 \\
\hline 16 & -1 & -1 & -1 & -1 & 1 & 292 \\
\hline 17 & 1 & 1 & 1 & 1 & -1 & 3038 \\
\hline 18 & -1 & 1 & 1 & 1 & -1 & 1377 \\
\hline 19 & 1 & -1 & 1 & 1 & -1 & 1642 \\
\hline 20 & -1 & -1 & 1 & 1 & -1 & 1490 \\
\hline 21 & 1 & 1 & -1 & 1 & -1 & 1638 \\
\hline 22 & -1 & 1 & -1 & 1 & -1 & 933 \\
\hline 23 & 1 & -1 & -1 & 1 & -1 & 1100 \\
\hline 24 & -1 & -1 & -1 & 1 & -1 & 1002 \\
\hline 25 & 1 & 1 & 1 & -1 & -1 & 823 \\
\hline 26 & -1 & 1 & 1 & -1 & -1 & 439 \\
\hline 27 & 1 & -1 & 1 & -1 & -1 & 2530 \\
\hline 28 & -1 & -1 & 1 & -1 & -1 & 1408 \\
\hline 29 & 1 & 1 & -1 & -1 & -1 & 1509 \\
\hline 30 & -1 & 1 & -1 & -1 & -1 & 1139 \\
\hline 31 & 1 & -1 & -1 & -1 & -1 & 1062 \\
\hline 32 & -1 & -1 & -1 & -1 & -1 & 1094 \\
\hline
\end{tabular}

showed wide variation of enzyme activity. In the present study, all factors positively regulated fibrinolytic enzyme production. The fibrinolytic enzyme production by Bacillus sp. IND12 varied from 292 to $3949 \mathrm{U} / \mathrm{g}$ in 32 experiments, which suggests the significance of medium components and their concentration on fibrinolytic enzyme production. The results showed that run number 3 resulted in the highest fibrinolytic enzyme production $(3949 \mathrm{U} / \mathrm{g})$, followed by medium composition in run $14(3881 \mathrm{U} / \mathrm{g})$ (Table 4). The observed mean response of this two-level full-factorial design was $1621.13 \mathrm{U} / \mathrm{g}$. The main effect, $F$ value, and $P$ value of each factor are given in Table 5. According to these ANOVA results, the five variables such as $A, B, C, D$, and $E$ were statistically significant on fibrinolytic enzyme production. Among the variables, the most significant variable was moisture, which had highest correlation coefficient compared to the other tested factors. The linear, interactive, and quadratic coefficients such as $A C, A E, B C, B E, C D, A B C$, $A B D, A B E, A C E, B C E, B D E, C D E, A B C D, A B C E, B C D E$, and $A B C D E$ were also statistically significant. The regression equation involving the coded factors is

$$
\begin{aligned}
\operatorname{Enzyme} \operatorname{activity}(Y)= & +1654.88+180 A+88.25 B \\
& +214.19 C+141.31 D \\
& +265.88 E+215.69 A C \\
& -98.75 A E-249.06 B C \\
& -166.06 B D+115.25 B E
\end{aligned}
$$


TABLE 5: Results of ANOVA for the two-level full-factorial design.

\begin{tabular}{|c|c|c|c|c|c|}
\hline Source & Sum of squares & $\mathrm{df}$ & Mean square & $F$ value & $P$ value \\
\hline Model & $2.50 E+07$ & 22 & $1.13 E+06$ & 85.09 & $<0.0001$ \\
\hline$A$-moisture & $1.04 E+06$ & 1 & $1.04 E+06$ & 77.79 & $<0.0001$ \\
\hline$B-\mathrm{pH}$ & $2.49 E+05$ & 1 & $2.49 E+05$ & 18.7 & 0.0019 \\
\hline$C$-sucrose & $1.47 E+06$ & 1 & $1.47 E+06$ & 110.15 & $<0.0001$ \\
\hline$D$-peptone & $6.39 E+05$ & 1 & $6.39 E+05$ & 47.95 & $<0.0001$ \\
\hline$E-\mathrm{MgSO}_{4}$ & $2.26 E+06$ & 1 & $2.26 E+06$ & 169.73 & $<0.0001$ \\
\hline$A C$ & $1.49 E+06$ & 1 & $1.49 E+06$ & 111.7 & $<0.0001$ \\
\hline$A E$ & $3.12 E+05$ & 1 & $3.12 E+05$ & 23.41 & 0.0009 \\
\hline$B C$ & $1.99 E+06$ & 1 & $1.99 E+06$ & 148.94 & $<0.0001$ \\
\hline$B D$ & $8.83 E+05$ & 1 & $8.83 E+05$ & 66.21 & $<0.0001$ \\
\hline$B E$ & $4.25 E+05$ & 1 & $4.25 E+05$ & 31.89 & 0.0003 \\
\hline$C D$ & $1.76 E+06$ & 1 & $1.76 E+06$ & 131.75 & $<0.0001$ \\
\hline$A B C$ & $7.16 E+05$ & 1 & $7.16 E+05$ & 53.71 & $<0.0001$ \\
\hline$A B D$ & $4.35 E+05$ & 1 & $4.35 E+05$ & 32.62 & 0.0003 \\
\hline$A B E$ & $4.88 E+05$ & 1 & $4.88 E+05$ & 36.62 & 0.0002 \\
\hline$A C E$ & $2.03 E+05$ & 1 & $2.03 E+05$ & 15.2 & 0.0036 \\
\hline$B C E$ & $3.33 E+05$ & 1 & $3.33 E+05$ & 24.95 & 0.00017 \\
\hline$B D E$ & $5.43 E+06$ & 1 & $5.43 E+06$ & 407.68 & $<0.0001$ \\
\hline$C D E$ & $2.02 E+05$ & 1 & $2.02 E+05$ & 15.13 & 0.0037 \\
\hline$A B C D$ & $3.60 E+05$ & 1 & $3.60 E+05$ & 26.98 & 0.0006 \\
\hline$A B C E$ & $8.65 E+05$ & 1 & $8.65 E+05$ & 64.92 & $<0.0001$ \\
\hline$B C D E$ & $1.665 E+0.006$ & 1 & $1.665 E+0.006$ & 124.95 & $<0.0001$ \\
\hline$A B C D E$ & $1.75 E+06$ & 1 & $1.75 E+06$ & 131.05 & $<0.0001$ \\
\hline Residual & $1.20 E+05$ & 9 & 13327.68 & & \\
\hline Cor total & $2.51 E+07$ & 31 & & & \\
\hline
\end{tabular}

TABLE 6: Variables and their levels for central composite rotational design.

\begin{tabular}{lcccccc}
\hline Variables & Symbol & $-\alpha$ & -1 & Coded values & \\
& & 83.18 & 90 & 100 & 11 & 110 \\
\hline Moisture (\%) & $A$ & 0.33 & 0.5 & 0.75 & 116.82 \\
Sucrose (\%) & $B$ & 0.03 & 0.05 & 0.08 & 1.0 & 0.1 \\
$\mathrm{MgSO}_{4}(\%)$ & $C$ & & 0.17 \\
\hline
\end{tabular}

$$
\begin{aligned}
& +234.25 C D+149.56 A B C \\
& +116.56 A B D-123.5 A B E \\
& +79.56 A C E-101.94 B C E \\
& -412.06 B D E+79.37 C D E \\
& -106 A B C D+164.44 A B C E \\
& -228.13 B C D E \\
& -233.62 A B C D E .
\end{aligned}
$$

Among the factors, the coefficient estimate was high for moisture, sucrose, and $\mathrm{MgSO}_{4}$. Hence these three factors were selected for further studies. The middle value of the other two factors $(0.5 \%(\mathrm{w} / \mathrm{w})$ peptone and $\mathrm{pH} 8.0)$ was used for CCRD.
3.5. Response Surface Methodology. A CCRD was employed to find the interactions among significant independent factors (moisture, sucrose, and $\mathrm{MgSO}_{4}$ ). Each variable was analyzed at five coded levels $(-\alpha,-1,0,+1,+\alpha)$ (Table 6$)$. Enzyme assay was carried out and the experimental result was taken as response $Y$ (Table 7). The $F$-test for an ANOVA was generated to elucidate the significance of the model and understand the reliability of the regression model. The selected variables, moisture, sucrose, and $\mathrm{MgSO}_{4}$, were found to be significant $(P<0.05)$ (Table 8). The interactive effects such as $A B$, $B C, A^{2}, B^{2}$, and $C^{2}$ were also statistically significant. The determinant coefficient termed $R^{2}$ was calculated to be 0.9933 for fibrinolytic enzyme production by Bacillus sp. IND12, suggesting $99.33 \%$ of the variability in the response. The final equation in terms of coded factor can be written as follows:

Fibrinolytic enzyme $(Y)$

$$
=+2921.44+340.22 A-147.18 B-543.64 C
$$


TABLE 7: The matrix of the CCRD experiment and fibrinolytic enzyme activity.

\begin{tabular}{|c|c|c|c|c|}
\hline Run & $\begin{array}{c}\text { Moisture } \\
(A)\end{array}$ & $\begin{array}{c}\text { Sucrose } \\
(B)\end{array}$ & $\begin{array}{c}\mathrm{MgSO}_{4} \\
(C)\end{array}$ & Enzyme activity (U/g) \\
\hline 1 & -1 & 1 & 1 & 1198 \\
\hline 2 & 0 & 0 & 0 & 3047 \\
\hline 3 & 0 & 0 & 0 & 2740 \\
\hline 4 & 1 & 1 & -1 & 3508 \\
\hline 5 & 0 & 0 & 0 & 2890 \\
\hline 6 & 0 & -1.682 & 0 & 1509 \\
\hline 7 & 1 & -1 & 1 & 3505 \\
\hline 8 & 0 & 0 & 1.682 & 3972 \\
\hline 9 & 0 & 0 & 0 & 2754 \\
\hline 10 & -1 & -1 & 1 & 2142 \\
\hline 11 & 0 & 0 & -1.682 & 5916 \\
\hline 12 & 1 & -1 & -1 & 4048 \\
\hline 13 & 1.682 & 0 & 0 & 3032 \\
\hline 14 & -1.682 & 0 & 0 & 1861 \\
\hline 15 & 0 & 1.682 & 0 & 1047 \\
\hline 16 & 1 & 1 & 1 & 1670 \\
\hline 17 & -1 & -1 & -1 & 2314 \\
\hline 18 & 0 & 0 & 0 & 2940 \\
\hline 19 & -1 & 1 & -1 & 3600 \\
\hline 20 & 0 & 0 & 0 & 3150 \\
\hline
\end{tabular}

TABLE 8: Results of ANOVA for the CCRD.

\begin{tabular}{|c|c|c|c|c|c|}
\hline Source & Sum of squares & $\mathrm{df}$ & Mean square & $F$ value & $P$ value \\
\hline Model & $2.247 E+007$ & 9 & $2.497 E+006$ & 165.97 & $<0.0001$ \\
\hline$A$-moisture & $1.581 E+006$ & 1 & $1.581 E+006$ & 105.07 & $<0.0001$ \\
\hline$B$-sucrose & $2.958 E+005$ & 1 & $2.958 E+005$ & 19.66 & 0.0013 \\
\hline C- $\mathrm{MgSO}_{4}$ & $4.036 E+006$ & 1 & $4.036 E+006$ & 268.26 & $<0.0001$ \\
\hline$A B$ & $1.546 E+006$ & 1 & $1.546 E+006$ & 102.76 & $<0.0001$ \\
\hline$A C$ & 46056.13 & 1 & 46056.13 & 3.06 & 0.1108 \\
\hline$B C$ & $9.282 E+005$ & 1 & $9.282 E+005$ & 61.69 & $<0.0001$ \\
\hline$A^{2}$ & $4.454 E+005$ & 1 & $4.454 E+005$ & 29.60 & 0.0003 \\
\hline$B^{2}$ & $4.998 E+006$ & 1 & $4.998 E+006$ & 332.21 & $<0.0001$ \\
\hline$C^{2}$ & $7.207 E+006$ & 1 & $7.207 E+006$ & 479.03 & $<0.0001$ \\
\hline Residual & $1.505 E+005$ & 10 & & & \\
\hline Lack of fit & 20173.51 & 5 & 4034.702 & 2.98 & 0.131 \\
\hline Pure error & $1.303 E+005$ & 5 & & & \\
\hline Cor total & $2.263 E+007$ & 19 & & & \\
\hline
\end{tabular}

$$
\begin{aligned}
& -439.62 A B-75.87 A C-340.62 B C-175.81 A^{2} \\
& -588.93 B^{2}+707.19 C^{2}
\end{aligned}
$$

where $Y$ was the response of fibrinolytic yield and $A, B$, and $C$ were the coded terms for independent variables of moisture, sucrose, and $\mathrm{MgSO}_{4}$, respectively. The interactions of variables in the model were demonstrated as 3D response surface plots (Figures $3(\mathrm{a})-3(\mathrm{c})$ ). The $R^{2}$ value of the predicted model was 0.9848 , which was reasonable in agreement with adjusted
$R^{2}$ of 0.9874 . The adequate precision reflects on the signalto-noise ratio; the ratio of 55.662 indicates adequate signal of the model. The response surface curve shows the interaction between moisture and sucrose. Enzyme production was maximum at higher moisture content and decreased at lower moisture content (Figure 3(a)). The moisture content of SSF medium takes different optimum values with differing substrates. It was reported that $40 \%$ was optimum for the production of proteolytic enzyme using wheat bran and lentil husk as the substrate [57]; however, 140\% was registered as the optimum moisture content for green gram husk substrate 


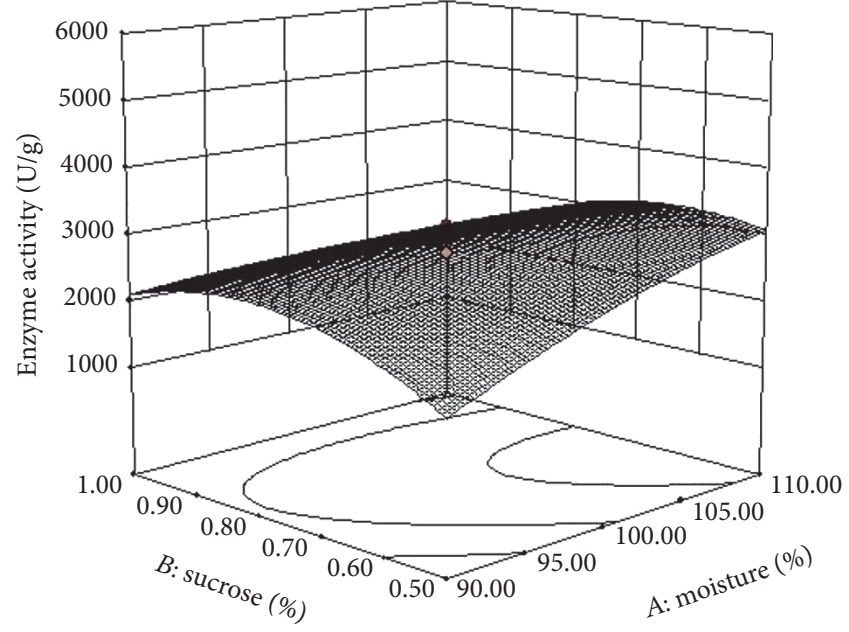

(a)

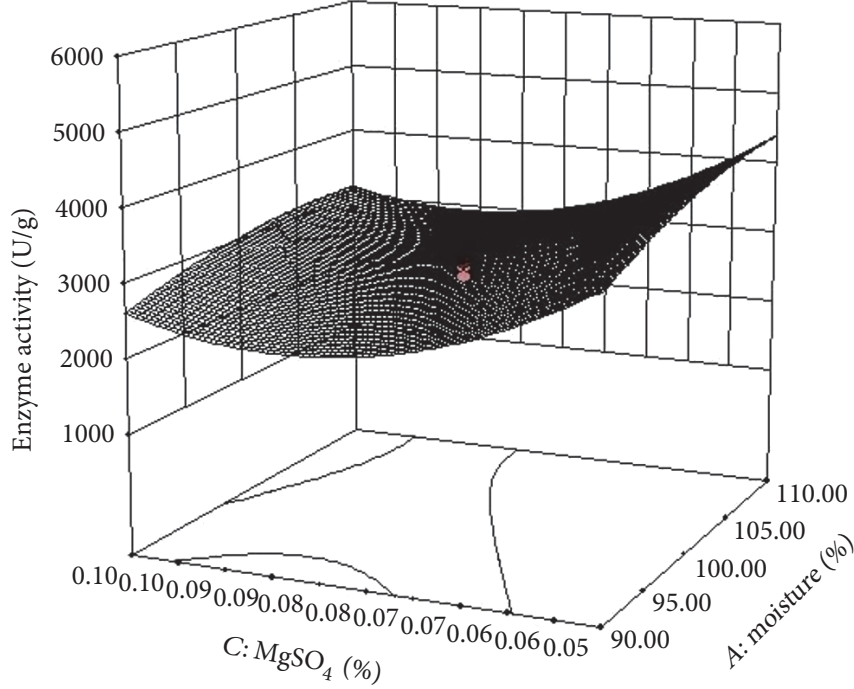

(b)

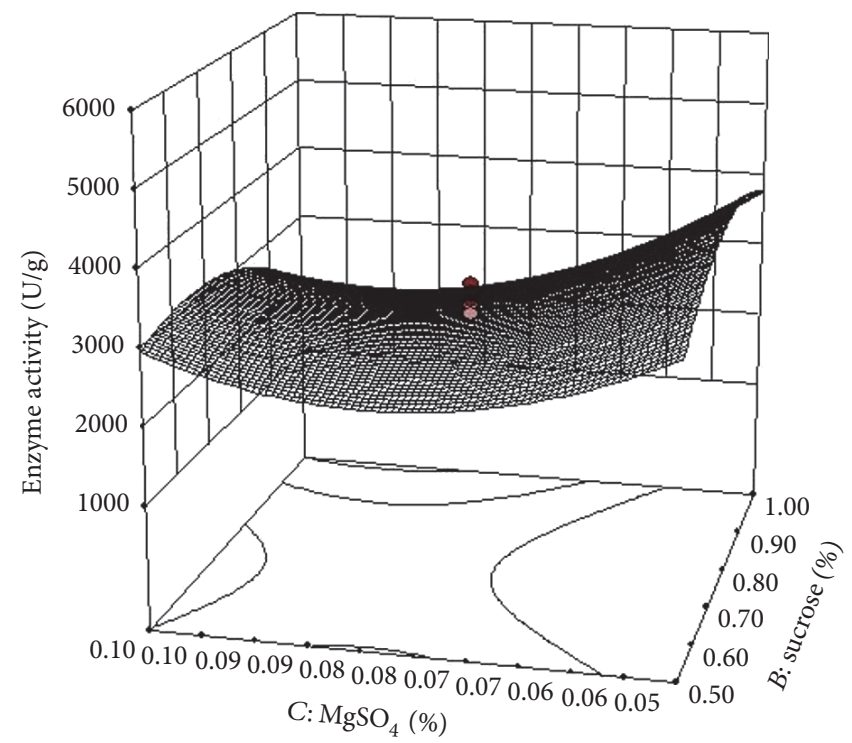

(c)

FIGURE 3: Response surface curve showing the effect of moisture and sucrose (a), moisture and $\mathrm{MgSO}_{4}$ (b), and sucrose and $\mathrm{MgSO}_{4}$ (c) on the fibrinolytic activity of Bacillus sp. IND12. The other factors ( $\mathrm{pH}$ and peptone) were kept at middle level.

for protease production [47]. In earlier reports of fibrinolytic enzyme production, many organic carbon sources have been used in the medium, including sucrose for Paenibacillus sp. IND8 [58], whereas glucose and soybean flour were used with Streptomyces sp. [59]. The data suggest that cow dung is a promising substrate for use in fibrinolytic enzyme production.

The three-dimensional response surface for the interaction of $\mathrm{MgSO}_{4}$ and moisture is represented (Figure 3(b)). The fibrinolytic enzyme yield was found to be increased with higher concentration of moisture. The results showed that fibrinolytic enzyme production was most affected by moisture levels compared to nutrient factors. In SSF, moisture content of the medium is critically important. The interaction of sucrose and $\mathrm{MgSO}_{4}$ indicated that fibrinolytic enzyme yield was significantly affected by interaction between these two factors (Figure 3(c)). The optimized medium (109.73\% moisture, $0.57 \%$ sucrose, and $0.093 \% \mathrm{MgSO}_{4}$ ) showed $4143 \pm$ $12.31 \mathrm{U} / g$ material, which was more than fourfold the unoptimized medium $(978 \pm 36.4 \mathrm{U} / \mathrm{g})$. Deepak et al. [60] reported similar optimization with RSM with Bacillus subtilis, which resulted in a twofold increase in fibrinolytic enzyme production. RSM was also employed for Bacillus sp. strain AS-S20-I [61] and Paenibacillus sp. IND8 [58], and 4-fold and 4.5-fold enzyme production was reported.

3.6. Validation of the Predicted Model. Validation experiments to test the appropriateness of the model were conducted with the strain IND12 under the following conditions: $109.73 \%$ moisture, $0.57 \%$ sucrose, and $0.093 \% \mathrm{MgSO}_{4}$. 
Fibrinolytic enzyme production reached the maximum of $4143 \pm 12.31 \mathrm{U} / \mathrm{g}$ after $72 \mathrm{~h}$ incubation, which was highly comparable with the predicted value $(4168.68 \pm 36.4 \mathrm{U} / \mathrm{g})$. The observed and predicted values went hand in hand, indicating the model validation.

3.7. Digestion of Proteins from Natural Sources by Bacillus $s p$. IND12 Protease. The ability of crude protease to digest some natural proteins was tested. The enzyme digested goat blood clot completely ( $100 \pm 0.92 \%$ solubility $)$ within $24 \mathrm{~h}$ of incubation at room temperature $\left(30^{\circ} \mathrm{C} \pm 2^{\circ} \mathrm{C}\right)$. These results showed that the fibrinolytic enzyme of Bacillus sp. IND12 can convert the insoluble forms of goat blood clot into soluble form. It also hydrolyzed $29 \pm 4.9 \%$ bovine serum albumin within $12 \mathrm{~h}$ of incubation. This enzyme digested coagulated egg white $(100 \pm 0.62 \%$ solubility) and also hydrolyzed chicken skin $(83 \pm 3.6 \%$ solubility). The study suggests the usefulness of this enzyme for various applications including collagen replacement therapy and waste treatment. These kinds of proteolytic activity were registered previously with Pseudomonas aeruginosa PD100 [62] and Bacillus RV.B2.90 [63]. The activity of the protease on egg protein, chicken skin, and blood clot indicates its importance in industrial application, waste treatment, and medicine.

\section{Conclusion}

To conclude, four-step screening was successful to evaluate the potent fibrinolytic enzyme-producing bacterial isolate. Cow dung was used as the cheap substrate for the production of fibrinolytic enzyme from Bacillus sp. IND12. The optimum process parameters were as follows: $109.73 \%$ moisture, $0.57 \%$ sucrose, and $0.093 \% \mathrm{MgSO}_{4}$. At these conditions, fibrinolytic enzyme production reached the maximum of $4143 \pm 12.31 \mathrm{U} / \mathrm{g}$ after $72 \mathrm{~h}$ incubation, which was highly comparable with the predicted value $(4168.68 \pm 36.4 \mathrm{U} / \mathrm{g})$. This enzyme hydrolyzed goat blood clot, chicken skin, egg white, and bovine serum albumin, which suggested its applications in clinical and waste water treatment. The bioprocessing of this low cost substrate can minimize the production cost of enzyme. The enhanced yield of fibrinolytic enzyme by Bacillus sp. IND12 using cow dung substrate could be useful for the production of enzyme in an industrial scale.

\section{Competing Interests}

The authors declare that they have no competing interests.

\section{Authors' Contributions}

Ponnuswamy Vijayaraghavan and Arumugaperumal Arun performed the majority of the experiments. Naif Abdullah Al-Dhabi, Mariadhas Valan Arasu, Oh Young Kwon, and Young Ock Kim analyzed the experimental data. P. Rajendran was involved in sequential screening assays. Samuel Gnana Prakash Vincent was involved in designing part of the experiments. All authors read and approved the final manuscript.

\section{Acknowledgments}

The funding from the Deanship of Scientific Research at King Saud University (PRG-1437-28) was sincerely appreciated.

\section{References}

[1] N. Mackman, "Triggers, targets and treatments for thrombosis," Nature, vol. 451, no. 7181, pp. 914-918, 2008.

[2] K. I. Fayek and S. T. El-Sayed, "Some properties of two purified fibrinolytic enzymes from Bacillus subtilis and B. polymyxa," Zeitschrift für Allgemeine Mikrobiologie, vol. 20, no. 6, pp. 383387, 1980.

[3] H. Malke and J. J. Ferretti, "Streptokinase: cloning, expression, and excretion by Escherichia coli," Proceedings of the National Academy of Sciences of the United States of America, vol. 81, no. 11, pp. 3557-3561, 1984.

[4] S.-L. Wang, H.-J. Chen, T.-W. Liang, and Y.-D. Lin, "A novel nattokinase produced by Pseudomonas sp. TKU015 using shrimp shells as substrate," Process Biochemistry, vol. 44, no. 1, pp. 7076, 2009.

[5] Y. Uesugi, H. Usuki, M. Iwabuchi, and T. Hatanaka, "Highly potent fibrinolytic serine protease from Streptomyces," Enzyme and Microbial Technology, vol. 48, pp. 7-12, 2011.

[6] P. Vijayaraghavan, S. G. P. Vincent, and M. Valan Arasu, "Purification, characterization of a novel fibrinolytic enzyme from Paenibacillus sp. IND8, and its in vitro thrombolytic activity," South Indian Journal of Biological Sciences, vol. 2, no. 4, pp. 434-444, 2016.

[7] P. Vijayaraghavan and S. G. Prakash Vincent, "Statistical optimization of fibrinolytic enzyme production using agroresidues by Bacillus cereus IND1 and its thrombolytic activity in vitro," BioMed Research International, vol. 2014, Article ID 725064, 11 pages, 2014.

[8] C.-T. Chang, P.-M. Wang, Y.-F. Hung, and Y.-C. Chung, "Purification and biochemical properties of a fibrinolytic enzyme from Bacillus subtilis-fermented red bean," Food Chemistry, vol. 133, no. 4, pp. 1611-1617, 2012.

[9] A. Pandey, C. R. Soccol, P. Nigam, D. Brand, R. Mohan, and S. Roussos, "Biotechnological potential of coffee pulp and coffee husk for bioprocesses," Biochemical Engineering Journal, vol. 6, no. 2, pp. 153-162, 2000.

[10] B. Johnvesly, B. R. Manjunath, and G. R. Naik, "Pigeon pea waste as a novel, inexpensive, substrate for production of a thermostable alkaline protease from thermoalkalophilic Bacillus sp. JB-99," Bioresource Technology, vol. 82, no. 1, pp. 61-64, 2002.

[11] A. K. Mukherjee, H. Adhikari, and S. K. Rai, "Production of alkaline protease by a thermophilic Bacillus subtilis under solidstate fermentation (SSF) condition using Imperata cylindrica grass and potato peel as low-cost medium: characterization and application of enzyme in detergent formulation," Biochemical Engineering Journal, vol. 39, no. 2, pp. 353-361, 2008.

[12] G. D. Saratale, S. D. Kshirsagar, V. T. Sampange et al., "Cellulolytic enzymes production by utilizing agricultural wastes under solid state fermentation and its application for biohydrogen production," Applied Biochemistry and Biotechnology, vol. 174, no. 8, pp. 2801-2817, 2014.

[13] T. Paul, A. Das, A. Mandal et al., "Effective dehairing properties of keratinase from Paenibacillus woosongensis TKB2 obtained under solid state fermentation," Waste and Biomass Valorization, vol. 5, no. 1, pp. 97-107, 2014. 
[14] B. L. Maiorella and F. J. Castillo, "Ethanol, biomass, and enzyme production for whey waste abatement," Process Biochemistry, vol. 19, no. 4, pp. 157-161, 1984.

[15] E. Ravindranath, K. Chitra, S. Shamshath Begum, and A. N. Gopalakrishnan, "Effect of recirculation rate on anaerobic treatment of fleshing using UASB reactor with recovery of energy," Journal of Scientific and Industrial Research, vol. 69, pp. 90-793, 2010.

[16] R. Siala, F. Frikha, S. Mhamdi, M. Nasri, and A. S. Kamoun, "Optimization of acid protease production by Aspergillus niger I1 on shrimp peptone using statistical experimental design," The Scientific World Journal, vol. 2012, Article ID 564932, 11 pages, 2012.

[17] A. E. Asagbra, A. I. Sanni, and O. B. Oyewole, "Solid-state fermentation production of tetracycline by Streptomyces strains using some agricultural wastes as substrate," World Journal of Microbiology and Biotechnology, vol. 21, no. 2, pp. 107-114, 2005.

[18] K. Prasad Kota and P. Sridhar, "Solid state cultivation of Streptomyces clavuligerus for cephamycin C production," Process Biochemistry, vol. 34, no. 4, pp. 325-328, 1999.

[19] D. Chakradhar, S. Javeed, and A. P. Sattur, "Studies on the production of nigerloxin using agro-industrial residues by solid-state fermentation," Journal of Industrial Microbiology and Biotechnology, vol. 36, no. 9, pp. 1179-1187, 2009.

[20] E. Venkata Naga Raju and G. Divakar, "Optimization and production of fibrinolytic protease (GD kinase) from different agro industrial wastes in solid state fermentation," Current Trends in Biotechnology and Pharmacy, vol. 7, no. 3, pp. 763-772, 2013.

[21] X. Wei, M. Luo, L. Xu et al., "Production of fibrinolytic enzyme from Bacillus amyloliquefaciens by fermentation of chickpeas, with the evaluation of the anticoagulant and antioxidant properties of chickpeas," Journal of Agricultural and Food Chemistry, vol. 59, no. 8, pp. 3957-3963, 2011.

[22] P. N. Nehete, V. D. Shah, and R. M. Kothari, "Profiles of alkaline protease production as a function of composition of the slant, age, transfer and isolate number and physiological state of culture," Biotechnology Letters, vol. 7, no. 6, pp. 413-418, 1985.

[23] O. Kirk, T. V. Borchert, and C. C. Fuglsang, "Industrial enzyme applications," Current Opinion in Biotechnology, vol. 13, no. 4, pp. 345-351, 2002.

[24] A. Gessesse and B. A. Gashe, "Production of alkaline protease by an alkaliphilic bacteria isolated from an alkaline soda lake," Biotechnology Letters, vol. 19, no. 5, pp. 479-481, 1997.

[25] J. Liu, J. Xing, T. Chang, Z. Ma, and H. Liu, "Optimization of nutritional conditions for nattokinase production by Bacillus natto NLSSE using statistical experimental methods," Process Biochemistry, vol. 40, no. 8, pp. 2757-2762, 2005.

[26] D. C. Montogomery, Design and Analysis of Experiments, John Wiley \& Sons, New York, NY, USA, 5th edition, 2001.

[27] H. Zhang, Q. Sang, and W. Zhang, "Statistical optimization of chitosanase production by Aspergillus sp. QD-2 in submerged fermentation," Annals of Microbiology, vol. 62, no. 1, pp. 193-201, 2012.

[28] B. Bhunia and A. Dey, "Statistical approach for optimization of physiochemical requirements on alkaline protease production from Bacillus licheniformis NCIM 2042," Enzyme Research, vol. 2012, Article ID 905804, 13 pages, 2012.

[29] P. Vijayaraghavan, S. G. Prakash Vincent, and G. S. Dhillon, "Solid-substrate bioprocessing of cow dung for the production of carboxymethyl cellulase by Bacillus halodurans IND18," Waste Management, vol. 48, pp. 513-520, 2016.
[30] P. Bressollier, F. Letourneau, M. Urdaci, and B. Verneuil, "Purification and characterization of a keratinolytic serine proteinase from Streptomyces albidoflavus," Applied and Environmental Microbiology, vol. 65, no. 6, pp. 2570-2576, 1999.

[31] Z. Hui, H. Doi, H. Kanouchi et al., "Alkaline serine protease produced by Streptomyces sp. degrades $\operatorname{PrP}(\mathrm{Sc})$," Biochemical and Biophysical Research Communications, vol. 321, no. 1, pp. 45-50, 2004.

[32] Y. Uesugi, J. Arima, H. Usuki, M. Iwabuchi, and T. Hatanaka, "Two bacterial collagenolytic serine proteases have different topological specificities," Biochimica et Biophysica Acta (BBA)— Proteins and Proteomics, vol. 1784, no. 4, pp. 716-726, 2008.

[33] S. Sugimoto, T. Fujii, T. Morimiya, O. Johdo, and T. Nakamura, "The fibrinolytic activity of a novel protease derived from a tempeh producing fungus, Fusarium sp. BLB," Bioscience, Biotechnology, and Biochemistry, vol. 71, no. 9, pp. 2184-2189, 2007.

[34] Johnson, Yanti, M. T. Suhartono, and B. W. Lay, "Isolation and purification of a fibrinolytic enzyme from bacterial strain isolated from tuak, an indonesian palm wine," International Journal of Pharma and Bio Sciences, vol. 6, no. 4, pp. B988-B996, 2015.

[35] P. Vijayaraghavan and S. G. P. Vincent, "A simple method for the detection of protease activity on agar plates using bromocresolgreen dye," Journal of Biochemical Technology, vol. 4, no. 3, pp. 628-630, 2013.

[36] M. F. Price, I. D. Wilkinson, and L. O. Gentry, "Plate method for detection of phospholipase activity in Candida albicans," Sabouraudia, vol. 20, no. 1, pp. 7-14, 1982.

[37] T. Astrup and S. Müllertz, "The fibrin plate method for estimating fibrinolytic activity," Archives of Biochemistry and Biophysics, vol. 40, no. 2, pp. 346-351, 1952.

[38] G. M. Kim, A. R. Lee, K. W. Lee et al., "Characterization of a 27 $\mathrm{kDa}$ fibrinolytic enzyme from Bacillus amyloliquefaciens $\mathrm{CH} 51$ isolated from Cheonggukjang," Journal of Microbiology and Biotechnology, vol. 19, no. 10, pp. 997-1004, 2009.

[39] J. G. Hol, N. R. Krieg, P. H. Sneath, J. J. Stanley, and S. T. Williams, Bergey's Manual of Determinative Bacteriology, Lippincott Williams \& Wilkins, Baltimore, Md, USA, 1994.

[40] T. S. Rejiniemon, R. R. Hussain, and B. Rajamani, "In-vitro functional properties of Lactobacillus plantarum isolated from fermented ragi malt," South Indian Journal of Biological Sciences, vol. 1, no. 1, pp. 15-23, 2015.

[41] S. F. Altschul, T. L. Madden, A. A. Schäffer et al., "Gapped BLAST and PSI-BLAST: a new generation of protein database search programs," Nucleic Acids Research, vol. 25, no. 17, pp. 3389-3402, 1997.

[42] M. L. Ansen, "The estimation of pepsin, trypsin, papain, and cathepsin with haemoglobin," Journal of General Physiology, vol. 22, pp. 78-79, 1939.

[43] O. H. Lowry, N. J. Rosebrough, A. L. Farr, and R. J. Randall, "Protein measurement with the Folin phenol reagent," The Journal of Biological Chemistry, vol. 193, no. 1, pp. 265-275, 1951.

[44] M. Fujita, K. Nomura, K. Hong, Y. Ito, A. Asada, and S. Nishimuro, "Purification and characterization of a strong fibrinolytic enzyme (nattokinase) in the vegetable cheese natto, a popular soybean fermented food in Japan," Biochemical and Biophysical Research Communications, vol. 197, no. 3, pp. 13401347, 1993.

[45] G. M. Kim, A. R. Lee, K. W. Lee et al., "Characterization of a $27 \mathrm{kDa}$ fibrinolytic enzyme from Bacillus amyloliquefaciens 
CH51 isolated from Cheonggukjang," Journal of Microbiology and Biotechnology, vol. 19, no. 2, pp. 997-1004, 2009.

[46] J. Yuan, J. Yang, Z. Zhuang, Y. Yang, L. Lin, and S. Wang, "Thrombolytic effects of Douchi Fibrinolytic enzyme from Bacillus subtilis LD-8547 in vitro and in vivo," BMC Biotechnology, vol. 12, article no. 36, 2012.

[47] R. S. Prakasham, C. Subba Rao, and P. N. Sarma, "Green gram husk: an inexpensive substrate for alkaline protease production by Bacillus sp. in solid-state fermentation," Bioresource Technology, vol. 97, no. 13, pp. 1449-1454, 2006.

[48] R. V. Misra, R. N. Roy, and H. Hiraok, On Farm Composting Method, FAO, Rome, Italy, 2003.

[49] C. D. Fulhage, Reduce Environmental Problems with Proper Land Application of Animal Manure, University of Missouri Extension, New York, NY, USA, 2000.

[50] D. V. Adegunloye, F. C. Adetuyi, F. A. Akinyosoye, and M. O. Doyeni, "Microbial analysis of compost using cowdung as booster," Pakistan Journal of Nutrition, vol. 6, no. 5, pp. 506-510, 2007.

[51] S. Tao, L. Peng, L. Beihui, L. Deming, and L. Zuohu, "Solid state fermentation of rice chaff for fibrinolytic enzyme production by Fusarium oxysporum," Biotechnology Letters, vol. 19, no. 5, pp. 465-467, 1997.

[52] W. Zeng, W. Li, L. Shu, J. Yi, G. Chen, and Z. Liang, "Nonsterilized fermentative co-production of $\operatorname{poly}(\gamma$-glutamic acid) and fibrinolytic enzyme by a thermophilic Bacillus subtilis GXA-28," Bioresource Technology, vol. 142, pp. 697-700, 2013.

[53] D. J. Mukesh Kumar, R. Rakshitha, M. Annu Vidhya et al., "Production, optimization and characterization of fibrinolytic enzyme by Bacillus subtilis RJAS19," Pakistan Journal of Biological Sciences, vol. 17, no. 4, pp. 529-534, 2014.

[54] R. R. Chitte and S. Dey, "Production of a fibrinolytic enzyme by thermophilic Streptomyces species," World Journal of Microbiology and Biotechnology, vol. 18, no. 4, pp. 289-294, 2002.

[55] P. Pillai, S. Mandge, and G. Archana, "Statistical optimization of production and tannery applications of a keratinolytic serine protease from Bacillus subtilis P13," Process Biochemistry, vol. 46, no. 5, pp. 1110-1117, 2011.

[56] S. S. Mabrouk, A. M. Hashem, N. M. A. El-Shayeb, A.-M. S. Ismail, and A. F. Abdel-Fattah, "Optimization of alkaline protease productivity by Bacillus licheniformis ATCC 21415," Bioresource Technology, vol. 69, no. 2, pp. 155-159, 1999.

[57] F. Uyar and Z. Baysal, "Production and optimization of process parameters for alkaline protease production by a newly isolated Bacillus sp. under solid state fermentation," Process Biochemistry, vol. 39, no. 12, pp. 1893-1898, 2004.

[58] P. Vijayaraghavan and S. G. P. Vincent, "Medium optimization for the production of fibrinolytic enzyme by Paenibacillus sp. IND8 using response surface methodology," The Scientific World Journal, vol. 2014, Article ID 276942, 9 pages, 2014.

[59] G. M. M. Silva, R. P. Bezerra, J. A. Teixeira, T. S. Porto, J. L. LimaFilho, and A. L. F. Porto, "Fibrinolytic protease production by new Streptomyces sp. DPUA 1576 from Amazon lichens," Electronic Journal of Biotechnology, vol. 18, no. 1, pp. 16-19, 2015.

[60] V. Deepak, K. Kalishwaralal, S. Ramkumarpandian, S. V. Babu, S. R. Senthilkumar, and G. Sangiliyandi, "Optimization of media composition for Nattokinase production by Bacillus subtilis using response surface methodology," Bioresource Technology, vol. 99, no. 17, pp. 8170-8174, 2008.

[61] A. K. Mukherjee and S. K. Rai, "A statistical approach for the enhanced production of alkaline protease showing fibrinolytic activity from a newly isolated Gram-negative Bacillus sp. strain AS-S20-I," New Biotechnology, vol. 28, no. 2, pp. 182-189, 2011.

[62] M. F. Najafi, D. Deobagkar, and D. Deobagkar, "Potential application of protease isolated from Pseudomonas aeruginosa PD100," Electronic Journal of Biotechnology, vol. 8, no. 2, pp. 197203, 2005.

[63] S. Vijayalakshmi, S. Venkatkumar, and V. Thankamani, "Screening of alkalophilic thermophilic protease isolated from Bacillus RV.B2.90 for Industrial application," Research in Biotechnology, vol. 2, pp. 32-41, 2011. 

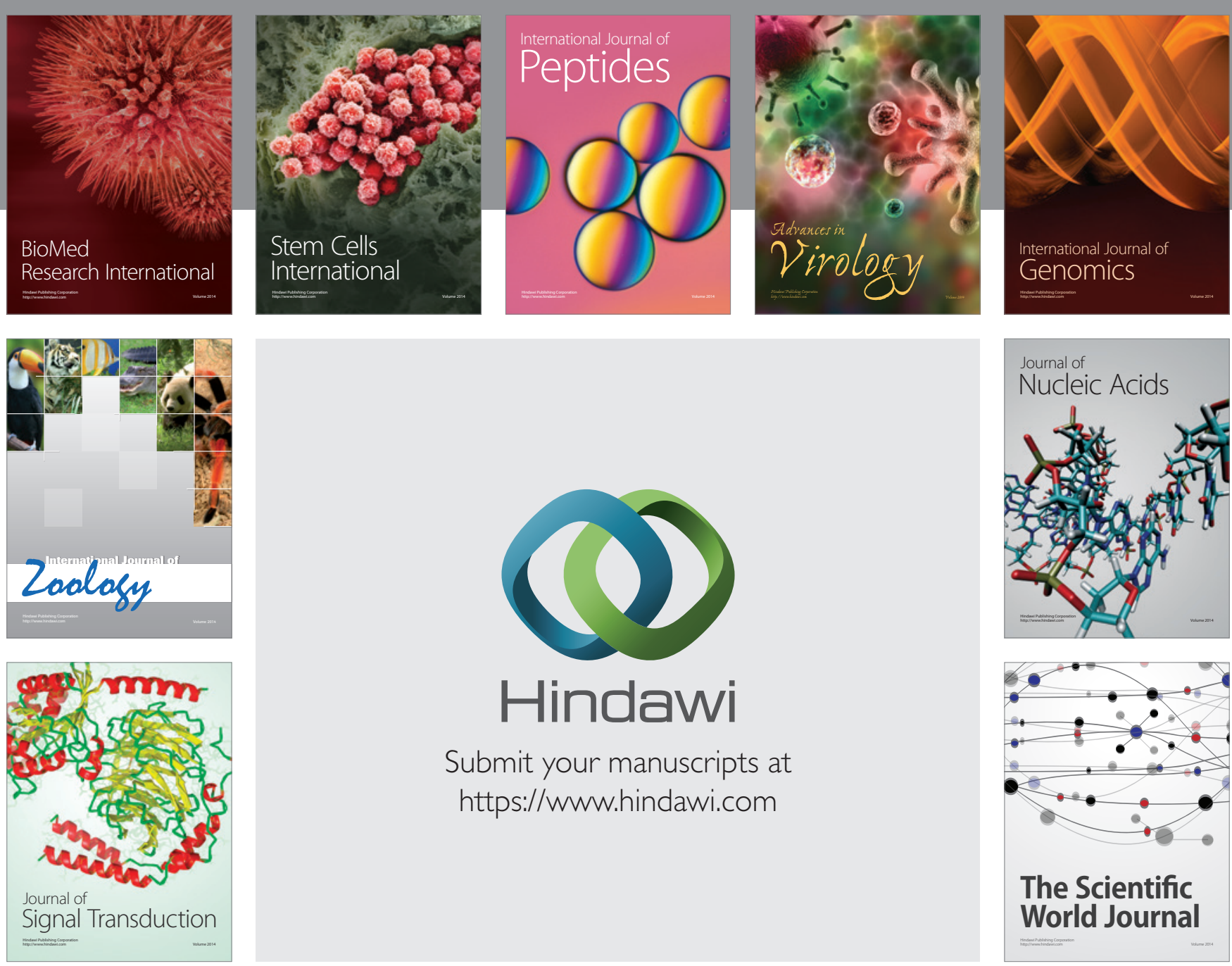

Submit your manuscripts at

https://www.hindawi.com
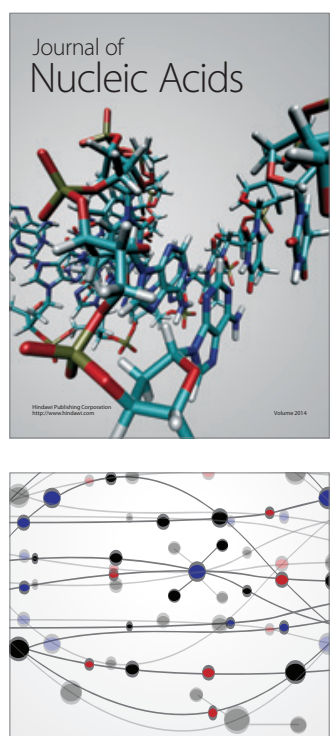

The Scientific World Journal
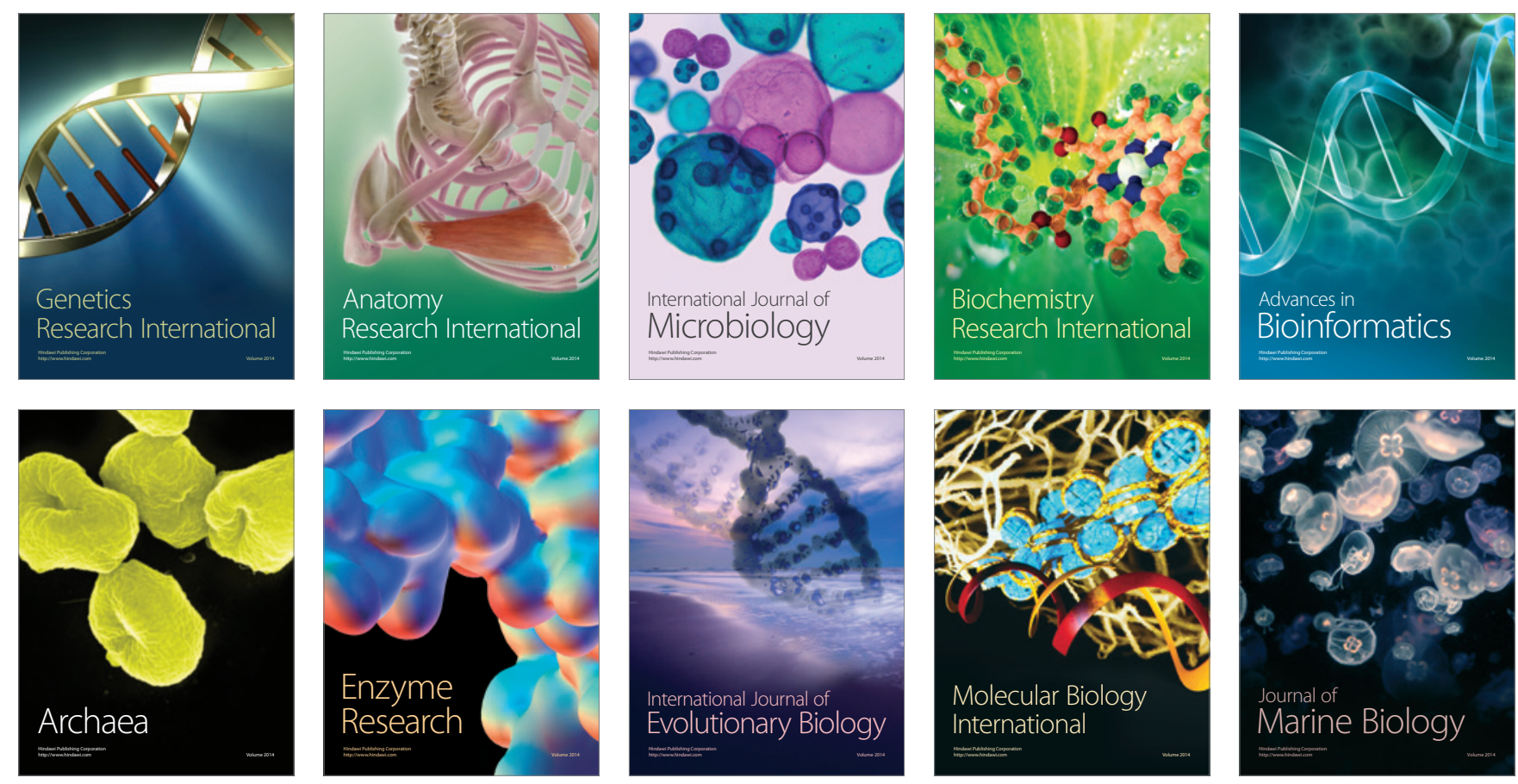